\author{
Л. М. Янів, О. А. Зінченко \\ Дніпропетровський національний університет імені Олеся Гончара, Україна
}

\title{
ПРОБЛЕМИ ДЕФІЦИТУ ДЕРЖАВНОГО БЮДЖЕТУ УКРАЇНИ І ШЛЯХИ ЇХ РОЗВ'ЯЗАННЯ
}

У період кризового стану економіки та соціально-економічної нестабільності в Україні дуже гостро постало питання дефіциту бюджету. Протягом останніх років державний бюджет України стикається 3 такою великою проблемою як дефіцит, що виникас внаслідок перевищення витрат державного бюджету над доходами.

Метою написання статті с дослідження наявних проблем дефіцитності державного бюджету України, обгрунтування причино-наслідкових зв'язківки у системі дефіцитного фінансування державної діяльності та розробка шляхів її оптимізації. Під час дослідження опрацьовано наукові праці українських учених та практиків, які вивчають проблеми дефіциту державного бюджету, законодавчі та урядові матеріали. Використано такі загальнонаукові методи: метод пізнання, метод системного аналізу, метод аналізу та синтезу, а також метод порівняння.

Розглянуто сутність дефіциту бюджетної системи та причини його виникнення в Україні. Глибинними причинами бюджетного дефіциту в Україні стали спад виробництва, зниження ефективності функціонування галузей економіки і підприсмств, не виважена соціальноекономічна політика, що $\mathbf{i}$ зумовили спад обсягів валового внутрішнього продукту i національного доходу. Це природно спричинило зменшення обсягів фінансових ресурсів у державі і відобразилось на показниках бюджету у вигляді довгострокового дефіциту.

Визначено залежність дефіциту бюджету від державного боргу. Встановлено, що існує тісний взасмозв'язок між розмірами бюджетного дефіциту i державного боргу. Бюджетний дефіцит збільшус державний борг, а зростання боргу, у свою чергу, потребус додаткових витрат бюджету на його обслуговування і тим самим збільшус бюджетний дефіцит.

Установлено зв'язки дефіциту бюджету для економіки країни. Виявлено наслідки підвищення відсоткової ставки, що, 3 одного боку, знижус інвестиційну привабливість на внутрішньому ринку країни, з іншого - підвищує іноземну валютну привабливість фінансових інвестицій країни. Значні інвалютні потоки призводять до зростання боргової залежності країни i, як наслідок, - зростання курсу валют, скорочення чистого експорту товарів та зниження показників інвестиційної діяльності. Таке скорочення с причина зниження рівня продуктивності праці й реального доходу в усіх його формах, що провокує зниження довіри інвесторів, а отже, скорочення іноземних інвестиційних програм і виведення капіталу за кордон.

Обгрунтовано шляхи подолання бюджетного дефіциту, що полягають у вдосконаленні податкової системи, залученні до інвестиційної сфери особистих заощаджень населення, забезпеченні фінансової підтримки малого та середнього бізнесу, посиленні відповідальності суб'єктів господарювання, зміцненні контролю за виплатою державних коштів, реформуванні видаткової системи, удосконаленні нормативно-правового забезпечення бюджетного процесу.

Наукова новизна дослідження полягас в установленні причино-наслідкових зв'язків бюджетних дефіцитів для наукового обгрунтування бюджетного менеджменту в період структурних перетворень економіки.

Практичним результатом с визначення шляхів реформування бюджетної системи України та її переходу до інвестиційної моделі.

Перспективним напрямом подальших досліджень у цій сфері с розробка на основі причино-наслідкових зв'язків моделі бюджетного процесу, здатної виявити ризики дефіциту та мінімізувати їх вплив.

Ключові слова: бюджет; бюджетний дефіцит; дефіцитне фінансування; державний борг; економіка.

(С Янів Л. М., Зінченко О. А., 2016 


\section{Л. Н. Янив, О. А. Зинченко.}

Днепропетровский национальный университет имени Олеся Гончара, Украина

\section{ПРОБЛЕМЫ ДЕФИЦИТА ГОСУДАРСТВЕННОГО БЮДЖЕТА УКРАИНЫ И ПУТИ ИХ РЕШЕНИЯ}

В период кризисного состояния экономики и социально-экономической нестабильности В Украине очень остро возник вопрос дефицита бюджета. В течение последних лет государственный бюджет Украины сталкивается с такой большой проблемой как дефицит, возникающий вследствие превышения расходов государственного бюджета над доходами.

Целью написания статьи является исследование существующих проблем дефицитности государственного бюджета Украины, обоснование причинно-следственных связей в системе дефицитного финансирования государственной деятельности и разработка путей ее оптимизации.

В ходе исследования были изучены научные работы украинских ученых и практиков, занимающихся проблемами дефицита государственного бюджета, законодательные и правительственные материалы. Использованы следующие общенаучные методы: метод познания, метод системного анализа, метод анализа и синтеза, а также метод сравнения.

Рассмотрены сущность дефицита бюджетной системы и причины его возникновения в Украине. Глубинными причинами бюджетного дефицита в Украине стали спад производства, снижение эффективности функционирования отраслей экономики и предприятий, несбалансированная социально-экономическая политика, что и обусловило спад объемов валового внутреннего продукта и национального дохода. Это естественно привело к сокращению величины финансовых ресурсов в государстве и отразилось на показателях бюджета в виде долгосрочного дефицита.

Определена зависимость дефицита бюджета от государственного долга. Установлено, что существует тесная взаимосвязь между размерами бюджетного дефицита и государственного долга. Бюджетный дефицит увеличивает государственный долг, а рост долга, в свою очередь, требует дополнительных расходов бюджета на его обслуживание и тем самым увеличивает бюджетный дефицит.

Установлены связи дефицита бюджета для экономики страны. Выявлены последствия повышения процентной ставки, что, с одной стороны, снижает инвестиционную привлекательность на внутреннем рынке страны, с другой - повышает иностранную валютную привлекательность финансовых инвестиций страны. Значительные инвалютные потоки приводят к росту долговой зависимости страны и, в результате к росту курса валют, сокращению чистого экспорта товаров и снижению показателей инвестиционной деятельности. Такое сокращение является причиной снижения уровня производительности труда и реального дохода во всех его формах, провоцирует снижение доверия инвесторов, а значит, сокращение иностранных инвестиционных программ и вывоз капитала за границу.

Обоснованы пути преодления бюджетного дефицита, заключающиеся в совершенствовании налоговой системы, привлечении к инвестиционной сфере личных сбережений населения, обеспечении финансовой поддержке малого и среднего бизнеса, усилении ответственности субъектов хозяйствования, укреплении контроля над выплатой государственных средств, реформировании расходной системы, совершенствовании нормативно-правового обеспечения бюджетного процесса.

Научная новизна исследования заключается в установлении причинно-следственных связей бюджетных дефицитов для научного обоснования бюджетного менеджмента в период структурных преобразований экономики.

Практическим результатом является определение путей реформирования бюджетной системы Украины и ее перехода к инвестиционной модели.

Перспективным направлением дальнейших исследований в этой сфере является разработка на основе причинно-следственных связей модели бюджетного процесса, способной выявить риски дефицита и минимизировать их влияние.

Ключевые слова: бюджет; бюджетный дефицит; дефицитное финансирование; государственный долг; экономика. 


\author{
L.M. Yaniv, O.A. Zinchenko. \\ Oles Honchar Dnipropetrovsk National University, Ukraine
}

\title{
THE PROBLEMS OF THE DEFICIT OF THE STATE BUDGET OF UKRAINE AND THE WAYS OF THEIR SOLVING
}

In the period of crisis situation in the economy and socio-economic instability in Ukraine, the problem of the budget deficit is very acute. In recent years the state budget of Ukraine has faced such a big problem as the deficit, due to the excess of spending over income of the state budget.

The purpose of writing this article is to research into existing problems of the deficit of the state budget of Ukraine, substantiate causal relationships in the system of insufficient funding of state activities and development of ways of its optimization. During the study we analyzed scientific papers by Ukrainian scientists and experts who explore the problem of the deficit of the state budget, legislative and government materials. We used the following general scientific methods: method of cognition, method of analysis, method of analysis and synthesis, as well as the method of comparison.

The essence of the deficit of the budget system and the reasons of its occurrence in Ukraine was considered. Underlying causes of budget deficit in Ukraine are slump in production, decrease in the efficiency of functioning of industries and businesses, unreasoned socio-economic policies, which led to a decline in the volume of gross domestic product and national income. This naturally caused a decrease in the volume of financial resources in the state and reflected in the indicators of the budget in the form of long-term deficit.

We defined the dependence of the budget deficit on the government debt. It is established that there is a close relationship between the size of the budget deficit and state debt. Budget deficit increases national debt, and rising debt, in turn, requires additional expenditures for its service and thereby increases the budget deficit.

The links of budget deficit to the country's economy were identified. We discovered the consequences of raising interest rate, which, on the one hand, reduces investment attractiveness in the domestic market of the country, on the other hand increases the attractiveness of the foreign financial investments in the country. Significant currency flows lead to the growth of the debt and, as a result, the growth of the currency exchange rate, reduction in the net exports of goods and decreased indicators of investment activity. This reduction is the reason for reducing the level of labour productivity and real income in all of its forms that provokes a decrease in investor confidence, and hence, reduces foreign investment programs and increases the withdrawal of capital abroad.

The ways of overcoming budget deficit were substantiated that are based on improving the taxation system, attracting personal savings of the population to the investment sphere, providing financial support to small and medium businesses, enhancing the responsibility of businesses, strengthening control over the payment of state money, reforming taxation system, improving normative and legal support of the budget process.

The scientific novelty of the research lies in the establishment of causal relationships of budget deficits for the scientific substantiation of budget management in the period of the structural transformation of the economy.

The practical result is to identify ways of reforming the budget system of Ukraine and its transition to the investment model.

A promising direction for further research in this area is developing a model of the budget process on the basis of causal relationships, which is capable of detecting the risks of deficiency and minimizing their impact.

Keywords: budget, budget deficit, deficit funding, national debt, economy.

Вступ. Протягом багатьох років державний бюджет України стикається 3 такою великою проблемою, як дефіцит, що виникає внаслідок перевищення витрат державного бюджету над доходами. Серед найвагоміших причин бюджетної розбалансованості в Україні виділяють: недосконалість і неефективність податкового законодавства, значний обсяг тіньової економічної діяльності, суттєві витрати на ведення воєнних дій, чималий рівень безробіття, залучення й 
використання позик для його покриття, зростання державного боргу з ризиком невиконання боргових зобов'язань, значний спад виробництва та інфляційні процеси, а також гальмування розвитку фінансової системи.

Проблематиці даної теми присвячено наукові праці та публікації вітчизняних та закордонних учених-економістів. Методологічною основою наукової праці $€$ статті, монографії вітчизняних науковців, які досліджують цю проблематику, нормативно-законодавчі акти, зокрема закони України «Про Державний бюджет України» та Бюджетний кодекс України. Значну увагу проблемам державного дефіциту бюджету та його впливу на економіку країни присвячено дослідження таких науковців: В. Бабіченко, С. Бойко, С. Булгакова [4], Н. Бурлачук, М. Матвійчук, Л. Маршук [7], А. Машко [2], І. Нечаюк [8].

Постановка завдання. Головна мета дослідження - розкрити сутність наявних проблем дефіцитності державного бюджету України, обгрунтувати причино-наслідкові зв'язки в системі дефіцитного фінансування державної діяльності та розробити шляхи ії оптимізації.

Результати. У період кризового стану економіки та соціально-економічної нестабільності в Україні дуже гостро постало питання дефіциту бюджету, що згідно зі ст. 2 Бюджетного кодексу України являє собою перевищення видатків бюджету над його доходами (з урахуванням різниці між наданням кредитів 3 бюджету та поверненням кредитів до бюджету) [1]. Найглибше основні характеристики цього поняття відображає його сутність.

Сутність бюджетного дефіциту як економічного явища в науковій літературі часто трактують як об’єктивні економічні відносини, що виникають між учасниками відтворювального процесу під час використання державою грошових коштів понад наявні доходи бюджету. Іншими словами, дефіцит виникає унаслідок незбалансованості бюджету, тобто нестачі грошових коштів для фінансування певного обсягу державних видатків [2, с. 310]. Відповідно, велике значення для економіки країни є 3'ясування причин його виникнення.

Глибинними причинами бюджетного дефіциту в Україні стали зниження виробництва, ефективності функціонування галузей економіки й підприємств, невиважена соціально-економічна політика, що зумовили зменшення обсягів валового внутрішнього продукту й національного доходу. Це природно зумовило скорочення величини фінансових ресурсів у державі, що й відобразилось на показниках бюджету у вигляді довгострокового дефіциту.

Серед конкретних причин виникнення бюджетної розбалансованості в Україні варто виокремити: неефективний механізм оподаткування суб'єктів господарювання, посилення фіскальної функції податкової системи; невпорядковану систему соціальних та економічних пільг; низьку якість бюджетного планування; нераціональну структуру бюджетних витрат; значний обсяг тіньової економічної діяльності; недосконалість і часту зміну фінансового законодавства тощо [4, с. 84$]$.

Ураховуючи вищесказане, доцільним буде навести показники зведеного бюджету України за останні 10 років (таблиця). 
Показники зведеного бюджету України за 2006-2015рр., млн грн*

\begin{tabular}{|c|c|c|c|c|c|c|}
\hline Рік & Доходи & $\begin{array}{c}\text { \% до } \\
\text { ВВП }\end{array}$ & $\begin{array}{c}\text { Видатки } \\
\text { (з кредитуванням) }\end{array}$ & ВВП дефіцит (-), & $\begin{array}{c}\text { до } \\
\text { профіцит (+) }\end{array}$ & ВВП \\
\hline 2006 & 171811,5 & 30,4 & 175512,2 & 31,06 & $-3700,7$ & $-0,65$ \\
\hline 2007 & 219936,5 & 29,3 & 227638,3 & 30,3 & $-7701,7$ & $-1,0$ \\
\hline 2008 & 297893,0 & 30,1 & 312017,5 & 31,5 & $-14124,5$ & $-1,4$ \\
\hline 2009 & 272967,0 & 29,8 & 310225,2 & 33,9 & $-37258,1$ & $-4,1$ \\
\hline 2010 & 314506,3 & 28,1 & 379191,2 & 33,8 & $-64684,9$ & $-5,8$ \\
\hline 2011 & 398553,6 & 29,5 & 421611,5 & 31,2 & $-23057,9$ & $-1,7$ \\
\hline 2012 & 445525,3 & 30,5 & 496311,0 & 34,0 & $-50785,7$ & $-3,5$ \\
\hline 2013 & 442788,7 & 29,1 & 506379,0 & 33,3 & $-63590,3$ & $-4,2$ \\
\hline 2014 & 456067,3 & 29,1 & 528097,8 & 33,7 & $-72030,5$ & $-4,6$ \\
\hline $2015^{* *}$ & 467937,2 & - & 435428,4 & - & $+32508,8$ & - \\
\hline
\end{tabular}

* Розробили автори за даними Міністерства фінансів України [5, с.11-12].

** За даними 3-го кварталу 2015 р.

3 показників державного бюджету в таблиці видно, що в динаміці (рис.1) за аналізований період сума видатків значно перевищує доходи та має тенденцію до збільшення, тому збільшується й рівень бюджетного дефіциту. Проте, за результатами 3-го кварталу 2015 р., можна говорити про можливість стабілізації економічного становища країни, оскільки отримано суттєвий профіцит бюджету.

Суттєвий показник профіциту в 2015 р. досягнено переважно за рахунок запозичень до державного бюджету, тобто так званого зовнішнього державного боргу. Згідно зі ст. 2 Бюджетного кодексу України, державний борг - це загальна сума боргових зобов'язань держави 3 повернення отриманих та непогашених кредитів (позик) станом на звітну дату, що виникають унаслідок державного запозичення.

Наприкінці 3-го кварталу 2015 р. сукупний борг України становив 46 480,9 млн дол. США, державний борг - 35 504,9 млн дол. США, а гарантований борг - 10 976,0 млн дол. США (рис. 2) [6].

3 динаміки зовнішнього державного боргу видно, що 3 кожним роком цей показник тільки зростає і тим самим збільшує імовірність зростання дефіциту бюджету.

Важливо зазначити, що існує тісний взаємозв'язок між розмірами бюджетного дефіциту й державного боргу. Бюджетний дефіцит збільшує державний борг, а зростання боргу, у свою чергу, потребує додаткових витрат бюджету на його обслуговування і збільшує бюджетний дефіцит [3]. У цьому випадку виникає боргова циклічність: бюджетний дефіцит - державні запозичення - державний борг - платежі за боргом - бюджетний дефіцит [4] (рис. 3). 


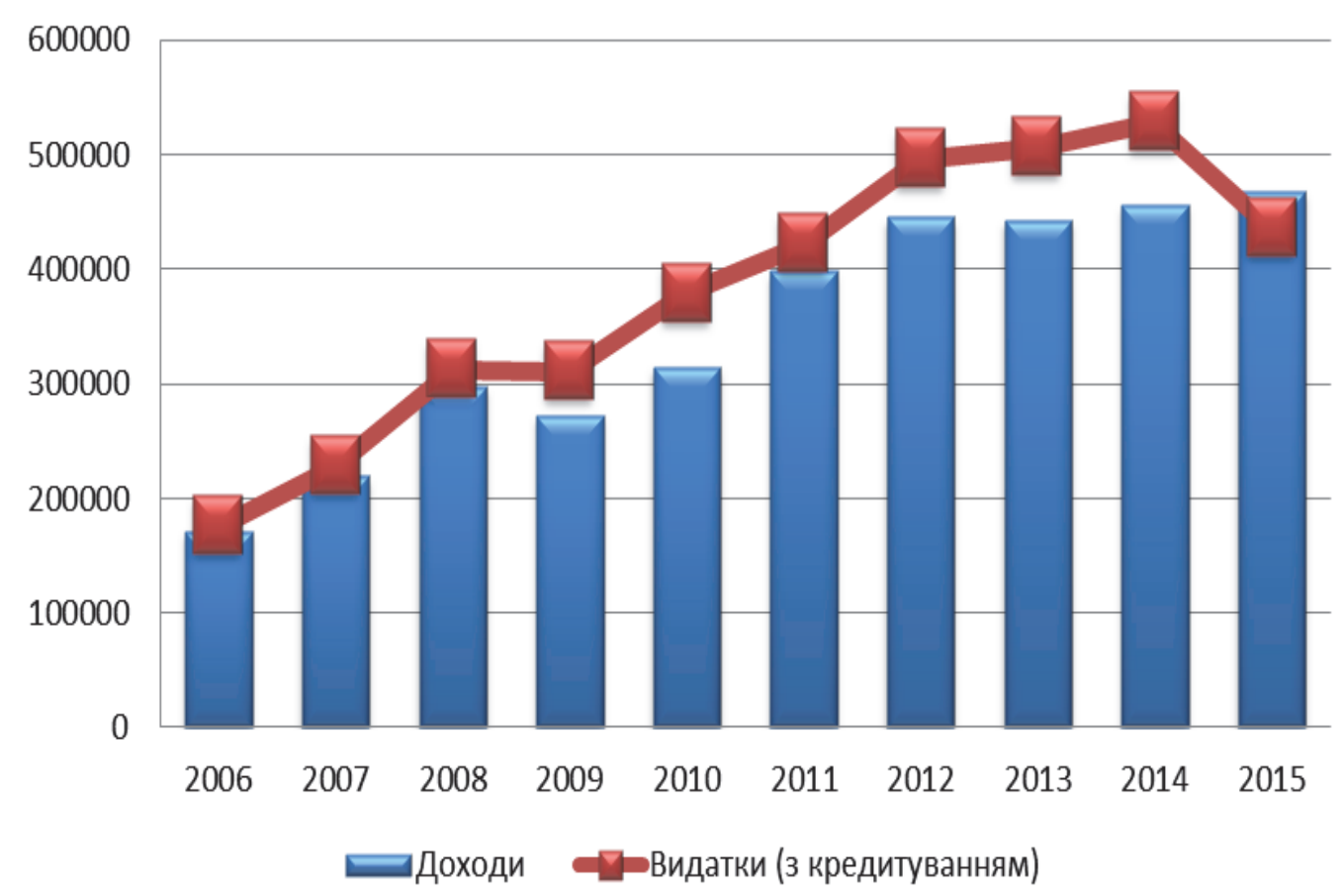

Рис. 1. Динаміка рівня доходів та видатків за 2006 - 2015 рр.

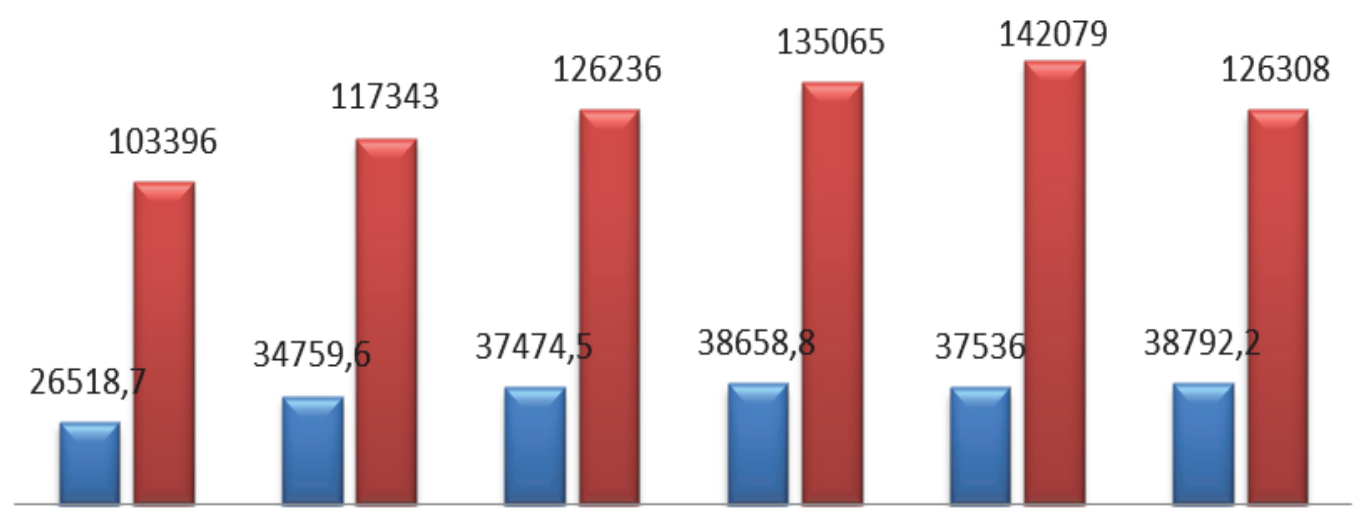

на 01.01.2010 на 01.01.2011 на 01.01.2012 на 01.01.2013 на 01.01.2014 на 01.01.2015

曰Зовнішній державний борг В Валовий зовнішній борг

Рис.2. Динаміка зовнішнього державного боргу та валового зовнішнього боргу України за 2010-2015 рр., млн дол. США *

*Розробили автори за даними [6] 


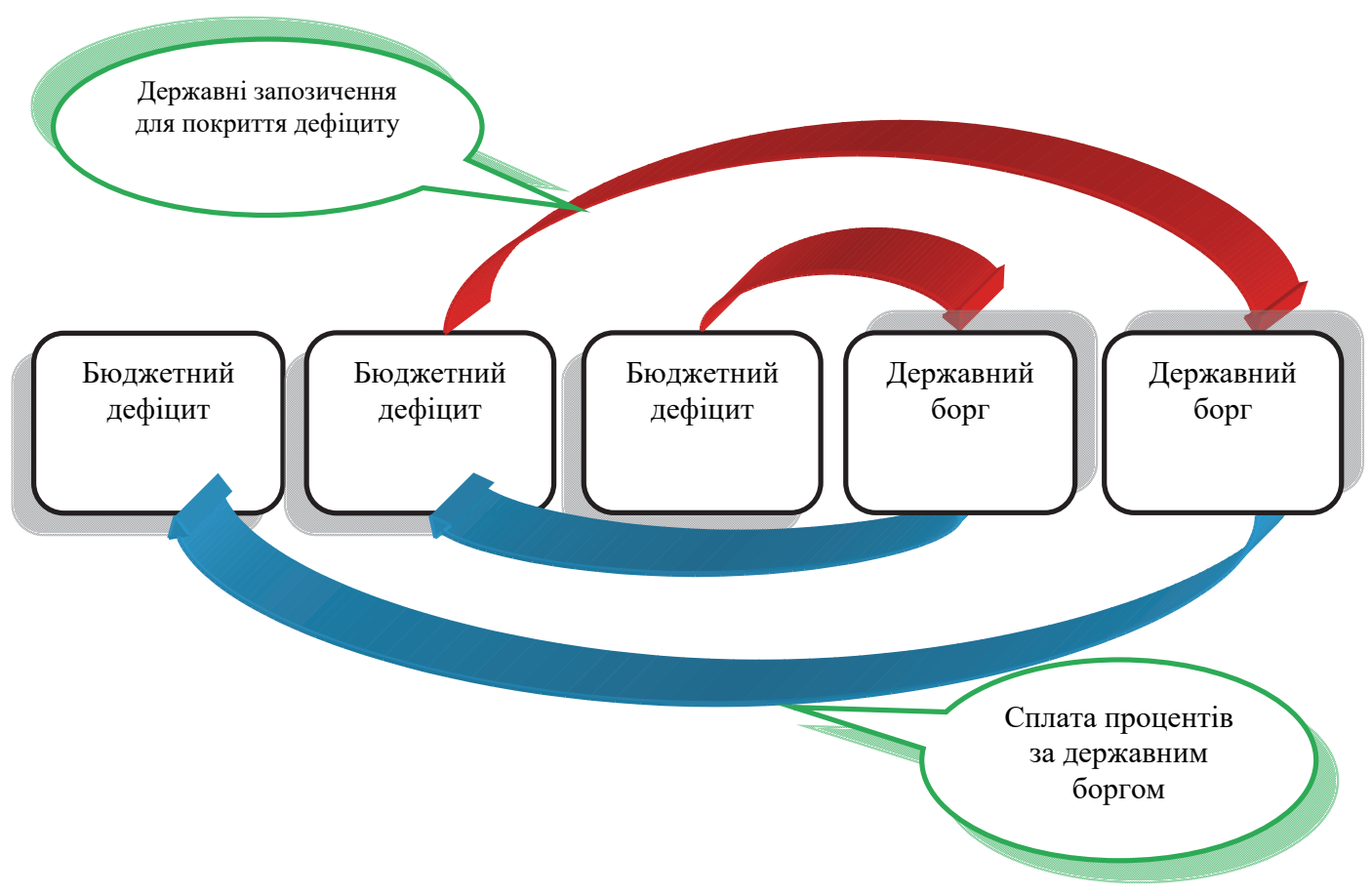

Рис. 3. Боргова циклічність

Боргова циклічність може призвести до багатьох негативних наслідків. Наведемо причинно-наслідкові зв'язки бюджетних дефіцитів (рис. 4) 3 метою розробити шляхи стабілізації цього явища:

1. Підвищення ставки процента має два наслідки. По-перше, він знижує приватні внутрішні інвестиції, особливо довготермінові. Державні кошти використовуються, як правило, на фінансове забезпечення найважливіших потреб населення. По-друге, підвищений процентний рівень за урядовими й комерційними цінними паперами підвищує іноземну валютну привабливість фінансових інвестицій країни.

2. Значні інвалютні потоки призводять до зростання боргової залежності країни. Закупівля найприбутковіших цінних паперів певної країни іноземцями припускає збільшення зацікавленості інших країн до національної валюти України. Така залежність підвищує загальносвітовий попит на цю валюту й курс валюти порівняно з іншими валютами на світовому валютному ринку.

3. Зростання курсу валют на міжнародному ринку, валюти певної країни знижує показник іiі експорту, що приводить до стимулювання імпорту. Скорочення чистого експорту товарів стримує розвиток експортно орієнтованих галузей.

4. Зниження інвестиційної діяльності зменшує капітал акціонерного товариства, виробничих потужностей, обсягів виробництва. Таке скорочення $\epsilon$ причина зниження рівня продуктивності праці й реального доходу в усіх його формах, що провокує зниження довіри інвесторів, а отже, скорочення іноземних інвестиційних програм і вивезення капіталу за кордон. 


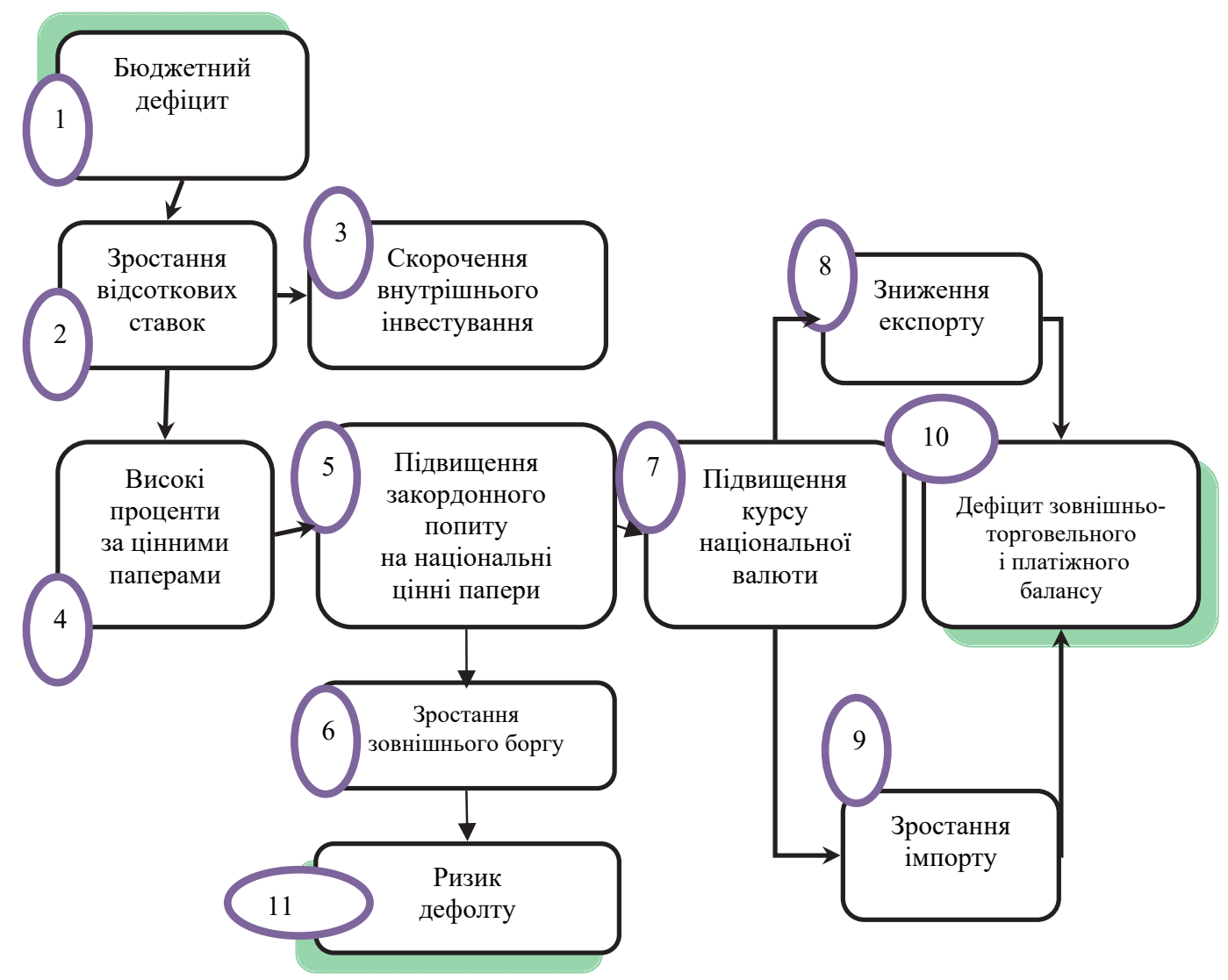

Рис.4. Причинно-наслідкові зв'язки бюджетного дефіциту [4, с. 86]

У підсумку, надмірний державний борг i дефіцит платіжного й зовнішньоторговельного балансу створює ризик дефолту - невиплати країною зобов'язань за державними запозиченнями. Дефолт може призвести до негативних для економіки країни і престижу держави наслідків, зумовлених згортанням інвестицій, збуванням цінних паперів нерезидентами, що спричиняє падіння їхньої вартості й подальше зростання процентних ставок [4, с.87].

Розгляд причинно-наслідкових зв'язків у системі дефіцитного фінансування державної діяльності дає підстави говорити про комплекс макрофінансових ефектів, які дестабілізують економічну ситуацію в країні, а отже, визначають необхідність реалізації ефективної політики керування бюджетним дефіцитом [7, с.32].

На основі проведеного дослідження доцільно буде запропонувати шляхи поліпшення стану економіки країни на майбутнє, бо бюджетний дефіцит потребує постійного пошуку шляхів його подолання, тобто збалансування доходів і витрат бюджету. Щоб знизити дефіцит держбюджету необхідно:

- удосконалити податкову систему, забезпечити оптимальний рівень податкових вилучень для формування бюджетів усіх рівнів i створення сприятливих умов для підприємницької діяльності; 
- залучити до інвестиційної сфери особисті заощадження населення;

- забезпечити фінансову підтримку малого та середнього бізнесу шляхом розробки i виконання цільових програм розвитку малого й середнього підприємництва;

- посилити відповідальність суб'єктів господарювання та їх керівників, зокрема особисту майнову і кримінальну відповідальність, за недотримання вимог законодавства, несвоєчасність і повноту розрахунків з бюджетом та державними позабюджетними фондами;

- скоротити видаткову частину бюджету: зменшити витрати на фінансування управлінських структур, створити жорсткий контроль за виплатою державних коштів;

- перейти від бюджетного фінансування до системи надання субсидій, субвенцій, інвестиційних позик суб'єктам господарювання;

- удосконалити нормативно-правове забезпечення бюджетного процесу [8, с.2].

У разі прийняття рішення стосовно затвердження бюджету 3 дефіцитом можна використати такі рекомендації:

країни;

- проводити ефективну політику 3 обслуговування державного боргу

- дефіцит державного бюджету підтримувати на рівні, не вищому за рівень інвестицій в основний капітал за рахунок коштів державного бюджету;

- формувати прогнозні показники дохідної та видаткової частини бюджету всіх рівнів на основі реальних даних;

- залучені кошти використовувати переважно для цільових державних програм, спрямованих на економічний розвиток $[8, \mathrm{c.2}]$.

Висновки. Підбиваючи підсумки проведеного дослідження, можна зробити висновок, що бюджетний дефіцит на сьогоднішній день досить актуальне та складне явище. Він являє собою перевищення видатків держбюджету над його доходами та є показник негативних явищ в економіці, що зумовлюють інфляцію грошової одиниці. На дефіцит бюджету впливають багато причин, головна з яких неефективність податкової та фіскальної політики держави. Через це протягом багатьох років бюджет був дефіцитним, оскільки не вистачало необхідних надходжень для покриття наявних витрат. Хоча й за результатами 3-го кварталу 2015 р. отримано профіцит, що не є прийнятний показник, бо паралельно із цим зріс і рівень державного боргу. Тому запропоновані заходи доцільні і обгрунтовані, оскільки економіка країни потребує негайних дій для свого розвитку.

Наукова новизна дослідження полягає встановленні причино-наслідкових зв'язки бюджетних дефіцитів для наукового обгрунтування бюджетного менеджменту в період структурних перетворень економіки.

Практичним результатом є визначення шляхів реформування бюджетної системи України та їі переходу до інвестиційної моделі.

Перспективним напрямом подальших досліджень в цій сфері $є$ розробка на основі причино-наслідкових зв'язки моделі бюджетного процесу, здатної виявити ризики дефіциту та мінімізувати їх вплив. 


\section{Бібліографічні посилання}

1. Бюджетний кодекс України від 08.07.2010 № 2456-VI [Текст] // Відом. Верховної Ради України (ВВР). - 2010. - № 50-51. - Ст.572.

2. Машко, А. Дефіцит бюджету: сутність, причини виникнення та проблеми управління [Текст] / А. Машко // Соціально-екон. проблеми і держава. - 2012. Вип. 2 (7). - С. 308-314.

3. Небава, М. І. Теорія макроекономіки [Текст]: навч. посіб. для студ. екон. спец. / М. І. Небава; Вінниц. держ. техн. ун-т. - Вінниця: УНІВЕРСУМ-Вінниця, 2005. $-536 \mathrm{c}$.

4. Бюджетна система [Текст] : підручник / В. В. Бабіченко [та ін.] / за наук. ред. В. М. Федосова, С. І. Юрія. - К.: Центр учбов. л-ри; Тернопіль : Екон. думка, 2012. $-871 \mathrm{c}$.

5. Статистичний збірник: «Бюджет України 2014» [Текст] / М-во фінансів України. - К.; 2015. - 308 с.

6. Внешний государственный долг Украины / Фін. портал МінФін [Електронний ресурс]. - Режим доступу: http://index.minfin.com.ua/ index/debt/gov. Заголовок з екрана.

7. Матвійчук, Н. М. Особливості бюджетного дефіциту України в сучасних умовах [Електронний ресурс] / Н. М. Матвійчук, Н. Ю. Бурлачук, Л. М. Маршук // Молодий вчений. - 2015. - № 5.- Режим доступу: http://molodyvcheny.in.ua/ files/journal/2015/5/45.pdf. - Заголовок з екрана.

8. Нечаюк, І. Б. Основні проблеми подолання бюджетного дефіциту в Україні [Текст] / І. Б. Нечаюк // Екон. форум. - 2013. - № 4. - С. 207-211.

Bibliographic references

1. Biudzhetnyi kodeks Ukrainy vid 08.07.2010 № 2456-VI // Vidom. Verkhovnoi Rady Ukrainy (VVR). - 2010. - № 50-51. - St.572.

2. Mashko, A. Defitsyt biudzhetu: sutnist, prychyny vynyknennia ta problemy upravlinnia / A. Mashko // Sotsialno-ekon. problemy i derzhava. - 2012. - Vyp. 2 (7). - S. 308-314.

3. Nebava, M. I. Teoriia makroekonomiky: navch. posib. dlia stud. ekon. spets. / M. I. Nebava; Vinnyts. derzh. tekhn. un-t. - Vinnytsia: UNIVERSUM-Vinnytsia, 2005. - $536 \mathrm{~s}$.

4. Biudzhetna systema: pidruchnyk / V. V. Babichenko [ta in.] / za nauk. red. V. M. Fedosova, S. I. Yuriia. - K.: Tsentr uchbov. 1-ry; Ternopil : Ekon. dumka, 2012. -871 s.

5. Statystychnyi zbirnyk: «Biudzhet Ukrainy 2014» / M-vo finansiv Ukrainy. - K.; 2015. - 308 s.

6. Vneshniy gosudarstvennyiy dolg Ukrainyi / Fin. portal MinFin [Electronic resource]. - Access mode: http://index.minfin.com.ua/ index/debt/gov.

7. Matviichuk, N. M. Osoblyvosti biudzhetnoho defitsytu Ukrainy v suchasnykh umovakh [Electronic resource] / N. M. Matviichuk, N. Iu. Burlachuk, L. M. Marshuk // Molodyi vchenyi. - 2015. - № 5. - Access mode: http://molodyvcheny.in.ua/ files/journal/2015/5/45.pdf.

8. Nechaiuk, I. B. Osnovni problemy podolannia biudzhetnoho defitsytu v Ukraini / I. B. Nechaiuk // Ekon. forum. - 2013. - № 4. - S. 207-211.

Надійшла до редколегії 10.03.2016 